\title{
A device for quantitative urine collection from male sheep in balance trials
}

\section{J. Kowalczyk, Beata Skiba, Z. Buczkowski and Barbara Kowalik}

The Kielanowski Institute of Animal Physiology and Nutrition,

Polish Academy of Sciences

05-110 Jablonna, Poland

(Received 6 May 1996; accepted 9 July 1996)

\begin{abstract}
A simple device for quantitative urine collection from male sheep kept in metabolic cages is described. The device consists of a modificd funnel-urinal fixed to the body of the animal. The urinal is made of: a soft plastic foil internal funnel that collects the urine; an external strong nylon tissue funnel to protect from mechanical damage; a plastic ring joining both funnels and ties fixing the funnels to the body; a connector joining the funncls with soft plastic flexible tube draining the excreted urine into the collection container. The device performed satisfactorily in numerous balance type experiments. An advantage of the described method is that it uses a simple, easily made device and prevents urine loss during collection. The urine is free of contamination with faeces and feed.
\end{abstract}

KEY WORDS: urine collection, male shecp

\section{INTRODUCTION}

Quantitative collection of urine in nitrogen, mineral, allantoin or other metabolite balance trials for male sheep is an integral part of many investigations. It is usually carried out using the classical method in metabolic cages with a perforated steel sheet or wooden wire-netting floor, described in detail in numerous papers by, e.g. Horn et al. (1954), Morrison (1957), Harris (1970), Watts (1976), Smith (1979). The disadvantage of this method is that urine is often splashed around the floor and usually contaminated with faeces and feeds and difficult to collect quantitatively. These negative factors are hard to eliminate in practice and entail errors in estimation of the amount of components excreted in 
urine. This may lead to erroneous estimations of components excreted in urine and influence the reliability of the balance value. Another method of urine collection from male sheep or cattle is based on fixing different types of urinal funnels covering the penis of the animal as described by Ervin et al. (1959), Bredon et al. (1961), Wainman and Peterson (1963), Colebrook and Black (1980). Funnels fixed to the body were made of different materials such as tarpaulin or rubber. Materials like these were sometimes uncomfortable for animals, provoking chafing and difficult to keep fixed in the proper position (Ziołecka, 1969).

The objective of this work was to elaborate a simple but efficient device for quantitative urine collection without contamination with faeces and feeds.

\section{MATERIAL AND METHODS}

\section{Description of device}

A simple device was constructed and applied for urine collection from male sheep kept in metabolic cages as demonstrated on Figure 1 . The device consists of a soft internal funnel-shaped sleeve about $20 \mathrm{~cm}$ long (a) made of heat-fused (about $0.1-0.2 \mathrm{~mm}$ ) plastic foil to collect excreted urine and prevent urine leakage (Figure 2). This internal sleeve is covered by an external slecve to protect from mechanical damage. This sleeve has a shape similar to the internal sleeve and is made of a strong cloth, e.g. nylon tissue (b). Both sleeves are fixed by winding the upper edges around a plastic ring of about $12 \mathrm{~cm}$ diameter (c) and with 4 tapes (d) fastening the device to the body. Both internal and external lower ends of the collecting sleeves are connected with a clamp (e) to a short plastic connector (f) with soft, flexible plastic tubing $(\mathrm{g})$ draining urine into a container located under the cage floor. The hole in the floor through which the tube passes has a longitudinal opening to avoid damage to the tube by the moving animal and permits urine collection from an animal in any position. The device covering the penis is fixed to the body by the tapes tied over the back of the animal.

\section{Comparison urine cleanness}

Six weathers of about $34 \mathrm{~kg}$ body weight fed the same diet were placed in metabolic cages and daily urine with or without addition of sulphuric acid was collected quantitatively for 3 days using classic methods from 3 weathers and using the described device from another 3 animals. The urine was filtered and the dry matter of the particulates retained on the filter was measured. Bacteria number was counted in non-acidified urine. 


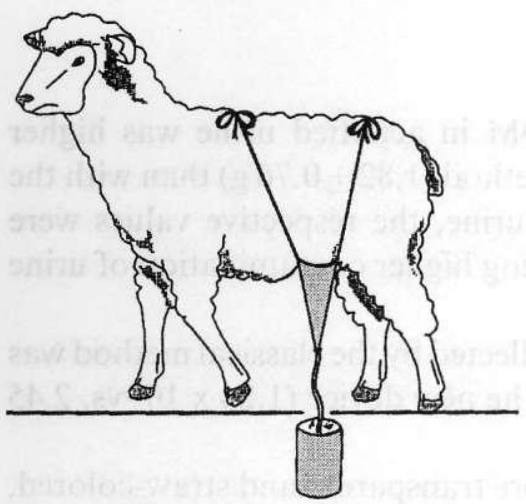

Figure 1. Fixing of device to the body
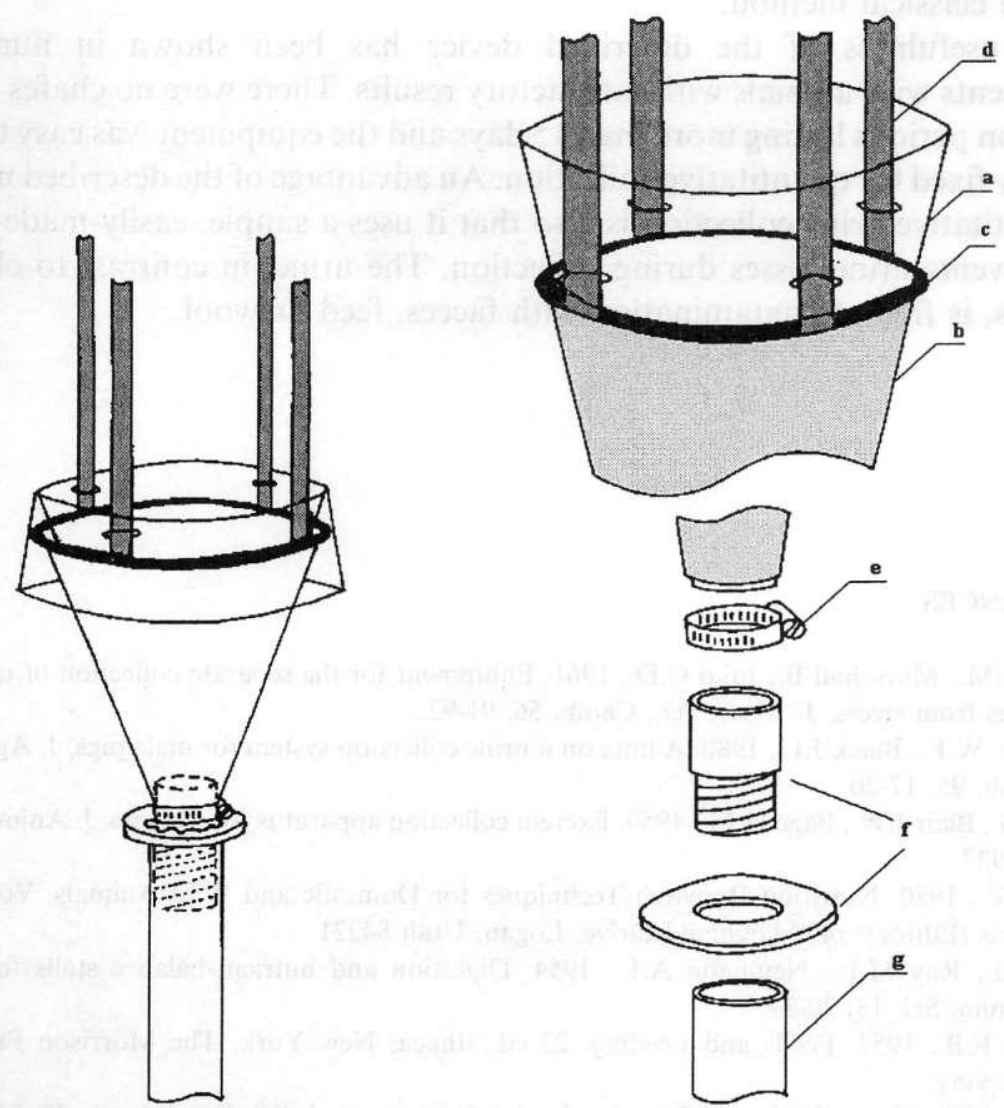

Figure 2. Device construction: $\mathrm{a}$ - internal thin plastic foil sleeve; $\mathrm{b}$ - external protective sleeve; $\mathrm{c}$ - plastic ring; $\mathrm{d}$ - tapies fixing device; $\mathrm{e}$ - clamp; $\mathrm{f}$ - connector; $\mathrm{g}$ - flexible plastic tube 


\section{RESULTS AND DISCUSSION}

The average daily amount of insoluble DM in acidified urine was higher $(\mathrm{P} \leqslant 0.01)$ in urine collected using the classic method $(1.82 \pm 0.76 \mathrm{~g})$ than with the tested device $(0.72 \pm 0.25 \mathrm{~g})$; in non-acidificd urine, the respective values were $1.98 \pm 0.47$ and $0.41 \pm 0.20 \mathrm{~g}(\mathrm{P} \leqslant 0.01)$ indicating higher contamination of urine collected classically.

The bacteria count in non-acidified urine collected by the classical method was higher $(\mathrm{P} \leqslant 0.01)$ than in urine collected with the new device $\left(1.24 \times 10^{5}\right.$ vs. 2.45 $\left.\mathrm{x} 10^{5} \mathrm{ml}^{-1}\right)$.

The urine collected using the device was more transparent and straw-colored, whereas urine collected with the classical method was dark brown. These results indicate that urine collected using the tested method was cleaner than collected with the classical method.

The usefulness of the described device has been shown in numerous experiments with animals with satisfactory results. There were no chafes during collection periods lasting more than 15 days and the equipment was easy to keep properly fixed for quantitative collection. An advantage of the described method of quantitative urine collection is also that it uses a simple, easily-made device and prevents urine losses during collection. The urine, in contrast to classical methods, is free of contamination with faeces, feed or wool.

\section{REFERENCES}

Bredon R.M., Marschall B., Juko C.D., 1961. Equjpment for the separate collection of urine and facces from steers. J. Agric. Sci., Cámb. 56, 91-92

Colebrook W.F., Black J.L., 1980. A note on a urine coltection system for male pigs. J. Agric. Sci., Camb. 95, 17-20

Erwin E.S., Blair J.W., Page H.M., 1959. Excreta collection apparatus for wethers. J. Anim. Sci. 18, 935-937

Harris L.E., 1970. Nutrition Research Techniques for Domestic and Wild Animals. Vol.1. L.E. Harris (Editor). 1408 Highland Drive, Logan, Utah 84321

Horn L.H., Ray M.L., Neumann A.L., 1954. Digestion and nutricnt-balance stalls for steers. J. Anim. Sci. 13, 20-24

Morrison F.B., 1957. Feeds and Feeding. 22 ed. Ithaca, New York, The Morrison Publishing Company

Smith T., 1979. The collection of faeces and urine from stecrs. J. Sci. Food Agric. 30, 215-217

Trela S., Krelowska M., 1963. A device for the collection of excrements from males (in Polish). Zesz. nauk WSR, Kraków, Ser. Zoot. 4, 29-32 
Wainman F.W., Peterson D., 1963. $\Lambda$ note on the collection of urine from male cattle and shecp. J. Agric. Sci, Camb. 61, 253-254

Watts P.R., 1976. A system for automatic collection and removal of urine from male farm animals. Brit. J. Nutr. 36, 295-297

Ziolecka $\Lambda ., 1969$. Investigations on the determination of digestibility in ruminants (in Polish). Rocz. Nauk rol., Ser. D - Monography 127, pp. I-153

\section{STRESZCZENIE}

Urządzenie do ilościowego ‘bierania moczu od tryków i skopów w doświadezeniach bilansowych

Opisano proste urządzenie do ilościowego zbierania moczu od tryków i skopów utrzymywanych w klatkach metabolicznych w doświadczeniach bilansowych. Urządzenie umocowane jest taśmami na ciele zwierzęcia i sk lada się $\%$ lejk owatego rękawa wewnętrznego wykonanego $z$ cienkiej, miekkiej folii plastykowej oraz podobnego ochronnego rękawa zewnętrznego wykonanego z mocncj tkaniny nylonowej. Obydwa lcjkowatc rękawy umocowane są na obrączee 7. pręla plasiykowego ( $4 \mathrm{~mm})$ z przytwierdzonymi taśmami mocującymi. Dolna, wę̇ssa c cęśś rękawa polączona jest łącznikiem z elastycznym wę̇em plastykowym odprowadzającym mocz do zbiornika.

Skutečność działania urządzenia sprawdzono w doświadczeniach bilansowych. Jest ono proste w wykonaniu, zapobiega stratom moczu podczas jego zbicrania, a mocz jest wolny od zanieczyszczeń kałem, rozsypywanej paszy lub sierści. 